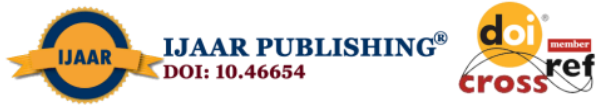 \\ International Journal of Advanced Academic Research | ISSN: 2488-9849 \\ Vol. 7, Issue 5, Series 2 (May, 2021) | www.ijaar.org \\ Journal DOI: www.doi.org/10.46654/ij.24889849 \\ Article DOI: www.doi.org/10.46654/ij.24889849.e1418
}

\section{ASSESSMENT OF PHYSICO-CHEMICAL CHARACTERISTICS AND HEAVY METAL CONCENTRATIONS OF STUBBS CREEK, IBENO, AKWA IBOM, NIGERIA}

\author{
*Anwan, Henry Robert ${ }^{1}$, Anetekhai, Martins Agenuma ${ }^{2}$ and Mekuleyi, Gabriel \\ Olarinde $^{2}$ \\ 1. Centre for Environmental Studies and Sustainable Development, Lagos State University, \\ Lagos, Nigeria \\ 2. Department of Fisheries, Lagos State University, Lagos, Nigeria \\ *Correspondence: anwan_henry@yahoo.com
}

\begin{abstract}
The present study examined some physico-chemical characteristics (temperature, $p H$, total hardness, dissolved oxygen (DO), total dissolved solid(TDS), conductivity, transparency, biochemical oxygen demand (BOD), acidity and alkalinity) and some heavy metals (Fe, Zn, $\mathrm{Cu}, \mathrm{Cd}, \mathrm{Cr}$ and $\mathrm{Ni}$ ) concentration of Stubbs Creek, Ibeno, Akwa Ibom, Nigeria between August 2014 and July, 2015. Six sampling stations (Mkpanak, Okpot Ikot, Ebana Mbri, Esit Eket, Okpuk and Ikot Ebia Anam) in Stubbs Creek were selected. Water samples were analyzed using APHA-AWWA-WPCF methods while heavy metals in the water samples were digested and determined using UNICAM 939 Atomic Absorption Spectrophotometer (AAS). The mean values of water parameters of Stubbs Creek are: temperature $\left(27.22 \pm 0.23^{\circ} \mathrm{C}\right)$; $\mathrm{pH}(6.83 \pm 0.13), \quad D O(3.86 \pm 0.20 \mathrm{mg} / \mathrm{L}), B O D(2.84 \pm 0.11 \mathrm{mg} / \mathrm{L})$, conductivity $(522.23$ $\left.\pm 69.12 \mu \mathrm{Scm}^{-1}\right), \operatorname{TDS}(288.83 \pm 39.50 \mathrm{mg} / \mathrm{L})$, transparency $(0.86 \pm 0.05 \mathrm{~m})$, alkalinity $(95.51 \pm$ $6.44 \mathrm{mg} / \mathrm{L})$, acidity $(97.03 \pm 7.45)$ and total hardness(12.11 1.55$).$ Only TDS, conductivity, alkalinity and total hardness showed significant $(p<0.05)$ spatial variation across the sampling stations. However, the values of temperature, TDS, conductivity, alkalinity and total hardness indicated significant seasonal variation. Similarly, there were no significant $(p<0.05)$ spatial and seasonal variation in the values of heavy metals recorded across the sampling stations. All the physico-chemical parameters and heavy metals in this study are below the maximum permissible limit recommended by WHO. The result showed that Stubbs Creek is less polluted at present and safe for the biota. However, responsible use of the water bodies by all and sundry should be maintained in order to preclude problems common with effluents discharge.
\end{abstract}

Key words: Water quality parameters, Heavy metals, Stubbs Creek, Safety. 


\section{Introduction}

Improper management of array of wastes and effluents generated by various anthropogenic activities remain a major challenge in developing countries. Progressive economic development over time and the discovery of oil in the Niger Delta, Nigeria, has led to the establishment of diverse industries, thus resulting in increased volume of wastes and effluent being discharged into the environment. Industrial effluent contain environmental contaminants which, when not properly treated prior to discharge, contaminate estuaries and inland water bodies, within the catchment area. Heavy metals are high priority pollutants because of their relatively toxic and persistent nature in the environment (Wangboje and Ekundayo, 2013). Besides disrupting the aquatic environment, the biological amplification of these toxic metals in the aquatic food chain constitutes a serious threat to public health (Ndimele, 2012). Reports have shown that high level of pollution with heavy metals result from atmospheric precipitation (El-Sayedet al., 2011), terrigenous activities (Sekabira et al., 2010), industrial discharge or domestic sewage and non-point source run-off (Ogundele and Mekuleyi, 2018).Pandey and Madhuri (2014), observed that in spite that some heavy metals are essential micronutrients, their toxic effects on living organisms via metabolic interference could lead to reduction in fitness, interference in reproduction leading to carcinoma, cancer, organ damage and eventually, death.

Stubbs Creek is deep brackish water and one of the water systems of the Niger Delta that contributes to the aquatic ecosystem resources of the region. Due to its strategic location, it serves as one of the prominent water bodies in Akwa Ibom State that is being exploited by many users for different purposes. Therefore, the present study is very pertinent as it aimed to provide information on the level of heavy metal concentration and status of physico-chemical parameters of Stubbs Creek.

\section{Materials and Methods}

\section{Study Area and Sampling Locations}

The study was carried out in Stubbs Creek (Figure 1) in Ibeno, Akwa Ibom State, Nigeria. It is strategically located at the Qua Ibo River Estuary in Ibeno, Akwa Ibom State. Six (6) sampling stations labeled A - F were established along the spatial grid of Stubbs Creek. Station A (Mkpanakat the inlet to the Creek, a distance of about $1.85 \mathrm{Km}$ from the beach) and station B (Okpot Ikot) about $1.5 \mathrm{~km}$ from station A in an open portion of the water course), station $\mathrm{C}$ (Ebana Mbri, within the head bridge area of the creek), station D (at the beginning of Esit Eket LGA), station E (Okpuk, about $1.5 \mathrm{Km}$ away from station D) and station F (Ikot Ebie Anam, about $1.5 \mathrm{Km}$ from station E).

\section{Collection of Samples}

Water samples were randomly collected twice in a month from the six sampling stations (Mkpanak, Okpot Ikot, Ebana Mbri, Esit Eket, Okpuk and Ikot Ebia Anam) in the Stubbs Creek, between August 2014 and July, 2015.Samples were collected by following methods described by APHA (2005). Prior to sampling, sample bottles were treated by soaking them in $10 \%$ nitric acid for $24 \mathrm{~h}$ and rinsed with distilled water. The water samples were collected at a depth of about $20 \mathrm{~cm}$ below water surface, into $750 \mathrm{~mL}$ plastic containers with lid. Air temperatures, $\mathrm{pH}$, dissolved oxygen (DO), conductivity, total dissolved solids (TDS) and transparency were determined in situ. Immediately after sample collection, $5 \mathrm{~mL}$ nitric acid 
(Analar grade) were added to the sample to reduce adsorption of metals onto the walls of the plastic (APHA, 2005). Biochemical oxygen demand (BOD), acidity, alkalinity and total hardness were determined according to methods described by APHA (2005). All samples were stored in a deep freezer at $-10^{\circ} \mathrm{C}$.

\section{Sample treatment for metal analysis}

Samples were defrosted at room temperature $\left(25^{\circ} \mathrm{C}\right)$ and filtered using whatman filter paper and digested according to the methods prescribed by APHA (2005). After digestion, the water samples were analyzed for $\mathrm{Cd}, \mathrm{Cr}, \mathrm{Cu}, \mathrm{Fe}, \mathrm{Ni}$ and $\mathrm{Zn}$ by Flame atomic absorption spectrophotometry (UNICAM model 939 Atomic Absorption Spectrophotometer). Instrument calibration and quality assurance checks were performed as per manufacturer's instructions.

\section{Statistical Analysis}

Data were computed using Statistical Package for the Social Sciences, windows version 17.0, (Chicago, USA). Spatial variations in the means values of physico-chemical parameters and heavy metals of water samples in the Stubbs Creek were determined using ANOVA and where there is significant variation, use of Duncan significant difference separate the means at a level of significance $\mathrm{p}<0.05$.

\section{Results}

Table 1 show the spatial variation of the heavy metals in Stubbs creek. The highest spatial mean value of $\mathrm{Fe}(2.06 \pm 0.23 \mathrm{mg} / \mathrm{L})$ was recorded in station D (Esit Eket) while the least $(1.52 \pm 0.15 \mathrm{mg} / \mathrm{L})$ was observed at station $\mathrm{E}$ (Okpuk). Zinc $(\mathrm{Zn})$ concentration measured during this study ranged from $1.04-2.98 \mathrm{mg} / \mathrm{L}$ with mean value of $1.67 \pm 0.05 \mathrm{mg} / \mathrm{L}$. Copper $(\mathrm{Cu})$ at Stubbs creek ranged from 0.00 to $2.20 \mathrm{mg} / \mathrm{L}$ with mean of $0.27 \pm 0.06 \mathrm{mg} / \mathrm{L}$. The lowest and highest values of $\mathrm{Cu}$ were recorded at station $\mathrm{B}$ and $\mathrm{F}(0.15 \pm 0.10,0.38 \pm 0.22)$ respectively. Cadmium $(\mathrm{Cd})$ concentration recorded during the period of study ranged from $0.00-0.06 \mathrm{mg} / \mathrm{L}$ with mean of $0.01 \pm 00 \mathrm{mg} / \mathrm{L}$. Chromium $(\mathrm{Cr})$ concentration measured during the period of study ranged from 0.01 to $0.73 \mathrm{mg} / \mathrm{L}$ with the mean of $0.14 \pm 0.02 \mathrm{mg} / \mathrm{L}$. $\mathrm{Ni}$ values for the study ranged from $0.18 \pm 0.05-0.22 \pm 0.08$. However, there was no significant ( $>0.05$ ) spatial variation of heavy metals concentration across the sampling stations (Table $1)$.

Similarly, there was no significant( $p>0.05)$ seasonal variation in the heavy metals across the stations (Fig. 2). On the contrary, the physico-chemical parameters(except pH, DO, BOD, and transparency)had significant $(\mathrm{p}<0.05)$ seasonal variation (Fig. 3). The values of the parameters in dry and wet seasons respectively are temp $\left(32.80 \pm 0.38^{0} \mathrm{C}, 27.30 \pm 0.377^{0} \mathrm{C}\right)$, electrical conductivity $(821.96 \pm 125.90 \mu \mathrm{s} / \mathrm{cm}, \quad 308.13 \pm 59.08 \mu \mathrm{s} / \mathrm{cm})$, TDS $(467.84 \pm 74.00$ $\mathrm{mg} / \mathrm{L}, 160.95 \pm 30.12 \mathrm{mg} / \mathrm{L})$, total hardness $(14.13 \pm 1.55 \mathrm{mg} / \mathrm{L}, 10.09 \pm 0.60 \mathrm{mg} / \mathrm{L})$, acidity $(101.49 \pm 7.45 \mathrm{mg} / \mathrm{L}, 92.57 \pm 7.04 \mathrm{mg} / \mathrm{L})$, alkalinity $(101.58 \pm \mathrm{mg} / \mathrm{L}, 91.16 \pm 9.22 \mathrm{mg} / \mathrm{L})$, $\mathrm{pH}(7.10,6.63), \mathrm{DO}(3.87 \pm 0.34 \mathrm{mg} / \mathrm{L}, 3.84 \pm 0.25 \mathrm{mg} / \mathrm{L})$, and transparency $(0.71 \pm 0.07 \mathrm{mg} / \mathrm{L}$, $0.96 \pm 0.05 \mathrm{mg} / \mathrm{L})$.

The spatial variation of physico-chemical parameters of Stubbs creek water is presented in Table 2. There were no significant $(\mathrm{p}>0.05)$ spatial variations in air temperature, water temperature, $\mathrm{DO}, \mathrm{pH}, \mathrm{BOD}$ and transparency across the stations. 


\section{Discussion}

There were no significant spatial and seasonal variations of heavy metals concentration across the sampling stations in this study. This could imply that the stations have similar heavy metals discharge. Similar non- significant seasonal and spatial variations of heavy metals in water samples have been reported in Ologe Lagoon (Ndimele et al.,2012).The metal concentrations in this study were lower than that reported by Agboola et al. (2008)in Badagry Creek, in Agbara by Ogundele and Mekuleyi (2018),in Ogba river at Benin city(Obasohan and Eguavoen, 2008)and Ologe Lagoon (Ndimele et al.,2011).Similarly, the values of heavy metals in this study are lower than those reported by Kamaruzzaman et al.(2011) and Mortuza and Al-Misned (2017).All the values of heavy metals recorded in this study are below the maximum permissible limits recommended by $\mathrm{WHO}(2017)$ and $\mathrm{EU}(2010)$. The values of TDS, conductivity, alkalinity, total hardness, and temperature which showed significant spatial and seasonal variations across the sampling stations could suggest that each sampling station is susceptible to different environmental stressors. Aderinola et al.(2016) and Akaahan et al.(2015) reported spatial variation across sampling sites in Badagry creek and River Benue respectively. The parameters are lower than that reported by Ndimele and Kumolu-Johnson (2012) and Ogundele and Mekuleyi(2018).All the physico-chemical parameters examined in this study (except TDS in stations A and B) were below the recommended permissible limits.

Reports have shown that the acidity and alkalinity of a water body influences the concentration of metals by altering their availability and toxicity (Lawson, 2011, Ashraf et al., 2012).Dissolved oxygen concentration and the $\mathrm{pH}$ of water bodies are important parameters that determine the spatial and temporal distribution of aquatic organisms, particularly the fish fauna (Araoye, 2009).Extreme lower $\mathrm{pH}$ can result in the death of many aquatic organisms while higher $\mathrm{pH}$ extremes can result in precipitation reactions and can also kill aquatic organisms. $\mathrm{pH}$ controls vital metabolic processes like respiration, which is the process by which living organisms produce energy (adenosine triphosphate) required for their activities.

$T D S$ content in water is a measure for salinity and its high content affects the density of water, influences freshwater organisms and reduces solubility of gases (like oxygen). Since, the TDS recorded in this study (except stations A and B) it is clear that the water is suitable for irrigation as reported by Singare et al. (2011).

BOD is a measure of the quality of the quantity of oxygen consumed by micro-organisms during the decomposition of organic matter. High BOD indicates presence of excessive amount of organic matter and hence poor water quality (Aderinola et al., 2016).

Conductivity is indication of nutrient and mineral levels of water. Low conductivity indicates good water quality while the high conductivity is an indicator of saline conditions. Studies have shown that high total hardness and low transparency is an indication of poor water quality (Edokpayi et al., 2010).

\section{Conclusion}

Sequel to the values of water parameters and heavy metals recorded in this study, it is certain that the water from Stubbs creek is less polluted and thus is suitable for irrigation and other 
International Journal of Advanced Academic Research | ISSN: 2488-9849

Vol. 7, Issue 5, Series 2 (May, 2021) |www.ijaar.org

Journal DOI: www.doi.org/10.46654/ij.24889849

Article DOI: www.doi.org/10.46654/ij.24889849.e1418

commercial uses such as fisheries. It could therefore be concluded that Stubbs creek is safe for the biota as well as human consumption. 


\section{References}

Aderinola, O.J., Adu, A.A. and Kusemiju,V. (2016). Baseline Study of Surface Water Chemistry of Badagry Creek, Lagos, Nigeria. International Journal of Science and Research (IJSR), 5(4):843-851.

Agboola, J. I., Anetekhai, M. A. and Denloye, A.B.(2008).Aspects of the Ecology and Fishes of Badagry Creek (Nigeria). Journal of Fisheries and Aquatic Science, 3: 184-194.

Akaahan, T. J. A., Olabanji, F. M. and Azua, E.T.(2015).Studies on contamination of surface waters of river Benue with trace elements at Makurdi, Benue State, Nigeria. Journal of Environmental Chemistry and Ecotoxicology, 7(5):49-55.

American Public Health Association (APHA) and American Water Works Association and Water (AWWA) Pollution Control Federation, (WPCF) (2005). Standard methods for the examination of water and waste water, 21st Edition. APHA, Washington DC.pp. 1273.

Ashraf, W., Seddigi, Z., Abulkibish, A. and Khalid, M.(2012). Levels of selected metals incanned fish consumed in Kingdom of Saudi Arabia. Environmental Monitoring Assessment, 117: 271 - 279.

El-sayed, E. A., El-Ayyat, M. S., El-Sayed, N. and Khater, Z. Z. K. (2011). Assessment of heavy metals in water, sediment and Fish tissues, from Sharkia Province, Egypt. Egyptian Journal of Aquatic Biology \& Fisheries, 15(2): 125-144.

Kamaruzzaman, B.Y., Shuhada, N.T., Zahir, M.S., Akbar, S.S., Jalal, K.C.A., Al-Barwani, S.M. and Goddard, J.S.(2011).Concentration of lead, copper and zinc in the bottom sediment of Tuba Island waters of Langkawi, Malaysia. Oriental Journal of Chemical, 27(2):505-510.

Lawson, E.O.(2011). Physico-Chemical Parameters and Heavy Metal Contents of Water from the Mangrove Swamps of Lagos Lagoon, Lagos, Nigeria. Biological Resources, 5(1): 08-21.

Mortuza, M.G. and Al-Misned, F.A.(2017). Environmental Contamination and Assessment of Heavy Metals in Water, Sediments and Shrimp of Red Sea Coast of Jizan, Saudi Arabia. Journal of Aquatic Pollution and Toxicology, 1:1-23.

Ndimele, P.E. and Kumolu-Johnson, C.A.(2012).Some Aspects of the Physicochemistry and Heavy Metal Content of Water, Sediment and Cynothrissa mento (Regan, 1917) from Badagry Creek, Lagos, Nigeria. Trend in Applied Science and Research, 7: 724-736.

Ndimele, P.E. (2012). "The Effects of Water Hyacinth (EichhornimaCrassipes[mark] Solms) Infestation on the Physico-Chemsitry, Nutrients and Heavy Metal Meal Content of Badagry Creek and Ologe Lagoon, Lagos. Nigeria Journal of Environmental Science 5 (2):128-136.

Obasohan, E. J., Oronsaye, A. O., and Obano, E. E.(2008). Heavy metal concentration in Malapterurus electricus and Chrysichthys nigrodigitatus from Ogba in Benin city, Nigeria. African J. Biotechnol., 5: 974-982. 
Olorunfemi, O. and Mekuleyi, G.O.(2018). Physico-chemical properties and heavy metals concentration in waste water discharged from two industries in Agbara, Lagos State, Nigeria International Research Journal of Public and Environmental Health,5 (3):3237.

Pandey, G. and Madhuri, S. (2014).Heavy Metals Causing Toxicity in Animals and Fishes Research Journal of Animal, Veterinary and Fishery Sciences, 2 (2), 17-23.

Sekabira, K.; OryemOriga, H.; Basamba, T. A.; Mutumba, G. and Kakudidi, E.(2010).Assessment of heavy metal pollution in the urban stream sediments and its tributaries, International Journal of Environmental Science and Technology, 7 (3), 435-446.

Singare, P.U., Lokhande, R.S. and Jagtap, A.G. (2011).Water pollution by discharge effluents from Gove Industrial Area of Maharashtra, India: Dispersion of heavy metals and their Toxic effects. International Journal of Global and Environmental Issues, 11(01):28-36.

Wangboje, O. M. and Ekundayo, O. T. (2013). Assessment of Heavy Metals in Surface Water of the Ikoba Reservoir, Benin City, Nigeria. "Nigerian Journal of Technology (NIJOTECH), Vol.32, No.1, 61-66.

$\mathrm{WHO}(2017)$. Guidelines for drinking-water quality: fourth edition incorporating the first addendum. Geneva: World Health Organization; 2017. Licence: CC BY-NC-SA 3.0IGO.T. 
Table 1: Spatial variations in heavy metals concentrations in Stubbs creek from August 2014 to July 2015.

\begin{tabular}{|c|c|c|c|c|c|c|}
\hline Metals & $\begin{array}{l}\text { Station A } \\
(\text { Mean } \pm \text { SE })\end{array}$ & $\begin{array}{l}\text { Station B } \\
(\text { Mean } \pm \text { SE })\end{array}$ & $\begin{array}{l}\text { Station C } \\
(\text { Mean } \pm \text { SE })\end{array}$ & $\begin{array}{l}\text { Station D } \\
(\text { Mean } \pm \text { SE })\end{array}$ & $\begin{array}{l}\text { Station E } \\
(\text { Mean } \pm \text { SE })\end{array}$ & $\begin{array}{l}\text { Station F } \\
(\text { Mean } \pm \text { SE })\end{array}$ \\
\hline $\mathbf{F e}$ & $2.05 \pm 0.37$ & $1.60 \pm 0.15$ & $1.85 \pm 0.18$ & $2.06 \pm 0.23$ & $1.52 \pm 0.15$ & $1.63 \pm 0.23$ \\
\hline Zn & $1.68 \pm 0.08$ & $1.75 \pm 0.10$ & $1.62 \pm 0.14$ & $1.60 \pm 0.15$ & $1.67 \pm 0.15$ & $1.69 \pm 0.18$ \\
\hline $\mathrm{Cu}$ & $0.27 \pm 0.15$ & $0.15 \pm 0.10$ & $0.30 \pm 0.17$ & $0.24 \pm 0.13$ & $0.29 \pm 0.17$ & $0.38 \pm 0.22$ \\
\hline Cd & $0.02 \pm 0.00$ & $0.01 \pm 0.00$ & $0.01 \pm 0.00$ & $0.01 \pm 0.00$ & $0.01 \pm 0.00$ & $0.01 \pm 0.00$ \\
\hline $\mathrm{Cr}$ & $0.15 \pm 0.06$ & $0.13 \pm 0.05$ & $0.14 \pm 0.06$ & $0.11 \pm 0.04$ & $0.16 \pm 0.06$ & $0.16 \pm 0.06$ \\
\hline $\mathbf{N i}$ & $0.18 \pm 0.05$ & $0.18 \pm 0.06$ & $0.22 \pm 0.08$ & $0.18 \pm 0.06$ & $0.21 \pm 0.08$ & $0.21 \pm 0.08$ \\
\hline
\end{tabular}

Means value with no superscripts along the same row are not significantly different 
Journal DOI: $\underline{w w w . d o i . o r g / 10.46654 / i j .24889849}$

Article DOI: www.doi.org/10.46654/ii.24889849.e1418

Table 2: Spatial variations in physico-chemical parameters in Stubbs creek

\begin{tabular}{lllllll}
\hline Parameters & $\begin{array}{l}\text { Station A } \\
(\mathbf{M e a n} \pm \text { SE) }\end{array}$ & $\begin{array}{l}\text { Station B } \\
(\mathbf{M e a n} \pm \mathbf{S E})\end{array}$ & $\begin{array}{l}\text { Station C } \\
(\mathbf{M e a n} \pm \text { SE) }\end{array}$ & $\begin{array}{l}\text { Station D } \\
(\text { Mean } \pm \text { SE) }\end{array}$ & $\begin{array}{l}\text { Station E } \\
(\mathbf{M e a n} \pm \text { SE) }\end{array}$ & $\begin{array}{l}\text { Station F } \\
(\mathbf{M e a n} \pm \mathbf{S E})\end{array}$ \\
\hline Air Temperature & $29.70 \pm 0.83$ & $30.19 \pm 1.07$ & $29.77 \pm 1.10$ & $29.50 \pm 1.04$ & $29.20 \pm 1.06$ & $29.35 \pm 1.22$ \\
$\mathrm{Ph}$ & $7.21 \pm 0.19$ & $6.81 \pm 0.34$ & $6.87 \pm 0.33$ & $6.54 \pm 0.39$ & $6.73 \pm 0.34$ & $6.83 \pm 0.37$ \\
Cond & $1198.50 \pm 217.07^{\mathrm{a}}$ & $668.68 \pm 159.19^{\mathrm{b}}$ & $380.06 \pm 119.98^{\mathrm{b}}$ & $353.90 \pm 113.01^{\mathrm{b}}$ & $362.23 \pm 142.73^{\mathrm{b}}$ & $170.03 \pm 58.93^{\mathrm{b}}$ \\
DO & $5.01 \pm 0.42$ & $4.57 \pm 0.59$ & $3.87 \pm 0.55$ & $3.42 \pm 0.41$ & $3.21 \pm 0.37$ & $3.06 \pm 0.46$ \\
BOD & $2.63 \pm 0.25$ & $2.84 \pm 0.24$ & $2.45 \pm 0.23$ & $3.01 \pm 0.36$ & $3.17 \pm 0.25$ & $2.95 \pm 0.31$ \\
TDS & $602.75 \pm 139.41^{\mathrm{a}}$ & $386.28 \pm 90.81^{\mathrm{ab}}$ & $204.87 \pm 61.66^{\mathrm{b}}$ & $245.68 \pm 85.04^{\mathrm{b}}$ & $195.89 \pm 75.95^{\mathrm{b}}$ & $97.48 \pm 34.49^{\mathrm{b}}$ \\
Transparency & $1.02 \pm 0.14$ & $0.91 \pm 0.12$ & $0.91 \pm 0.10$ & $0.81 \pm 0.07$ & $0.82 \pm 0.11$ & $0.69 \pm 0.11$ \\
Hardness & $15.87 \pm 3.19$ & $11.35 \pm 1.65$ & $10.69 \pm 1.15$ & $11.07 \pm 1.37$ & $10.36 \pm 1.49$ & $11.33 \pm 1.64$ \\
Acidity & $123.74 \pm 18.94$ & $91.86 \pm 9.52$ & $86.40 \pm 10.93$ & $83.12 \pm 12.25$ & $84.38 \pm 9.34$ & $108.22 \pm 9.94$ \\
Alkalinity & $145.97 \pm 20.80^{\mathrm{a}}$ & $102.15 \pm 20.06^{\mathrm{ab}}$ & $87.60 \pm 9.94^{\mathrm{b}}$ & $75.84 \pm 10.34^{\mathrm{b}}$ & $81.02 \pm 11.07^{\mathrm{b}}$ & $80.46 \pm 11.19^{\mathrm{b}}$
\end{tabular}

Means value with no superscripts along the same row are not significantly different 
International Journal of Advanced Academic Research | ISSN: 2488-9849

Vol. 7, Issue 5, Series 2 (May, 2021) |www.ijaar.org

Journal DOI: www.doi.org/10.46654/ij.24889849

Article DOI: www.doi.org/10.46654/ij.24889849.e1418

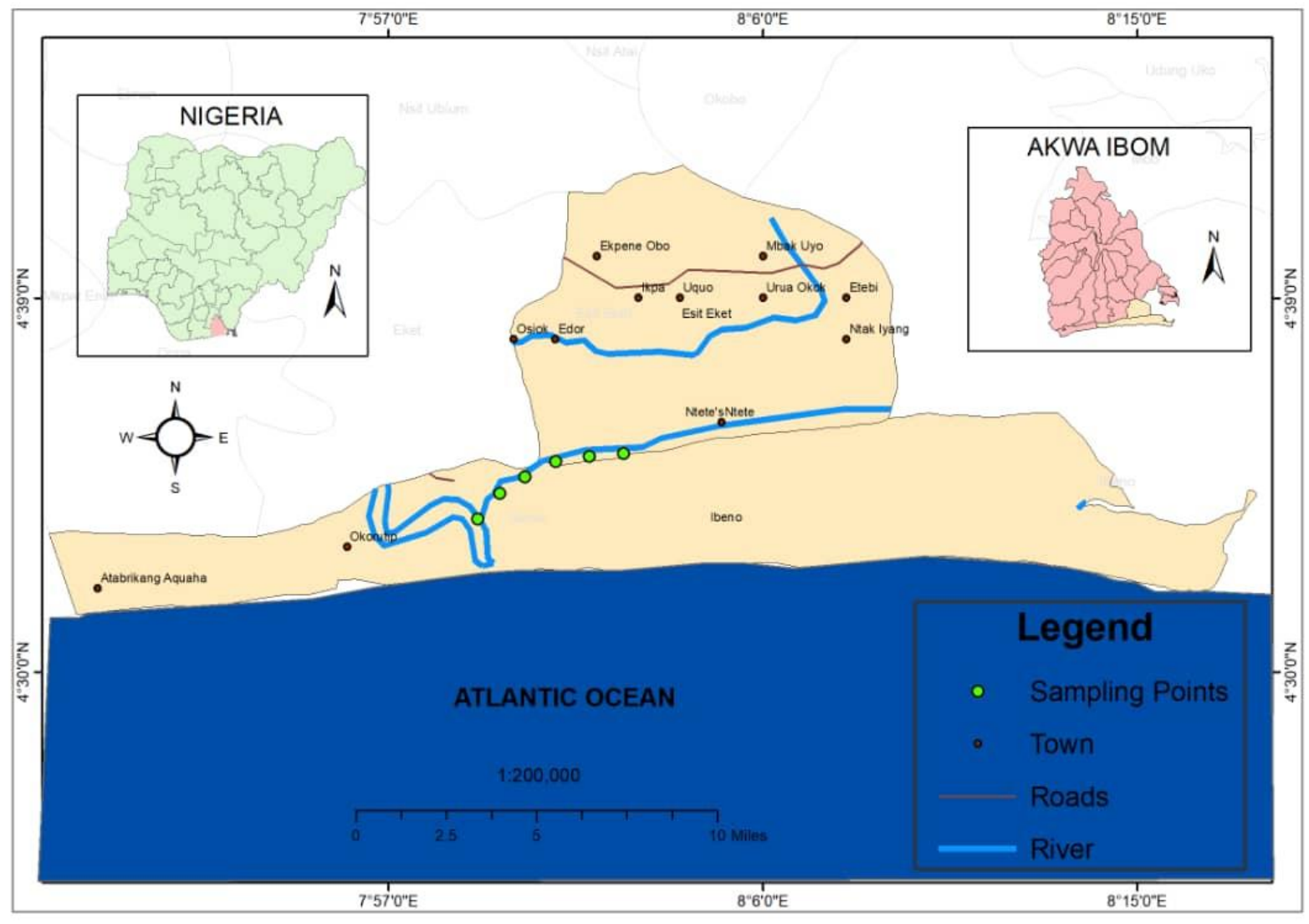

Figure 1: Map of Stubbs creek Ibeno showing the stations of sampling 


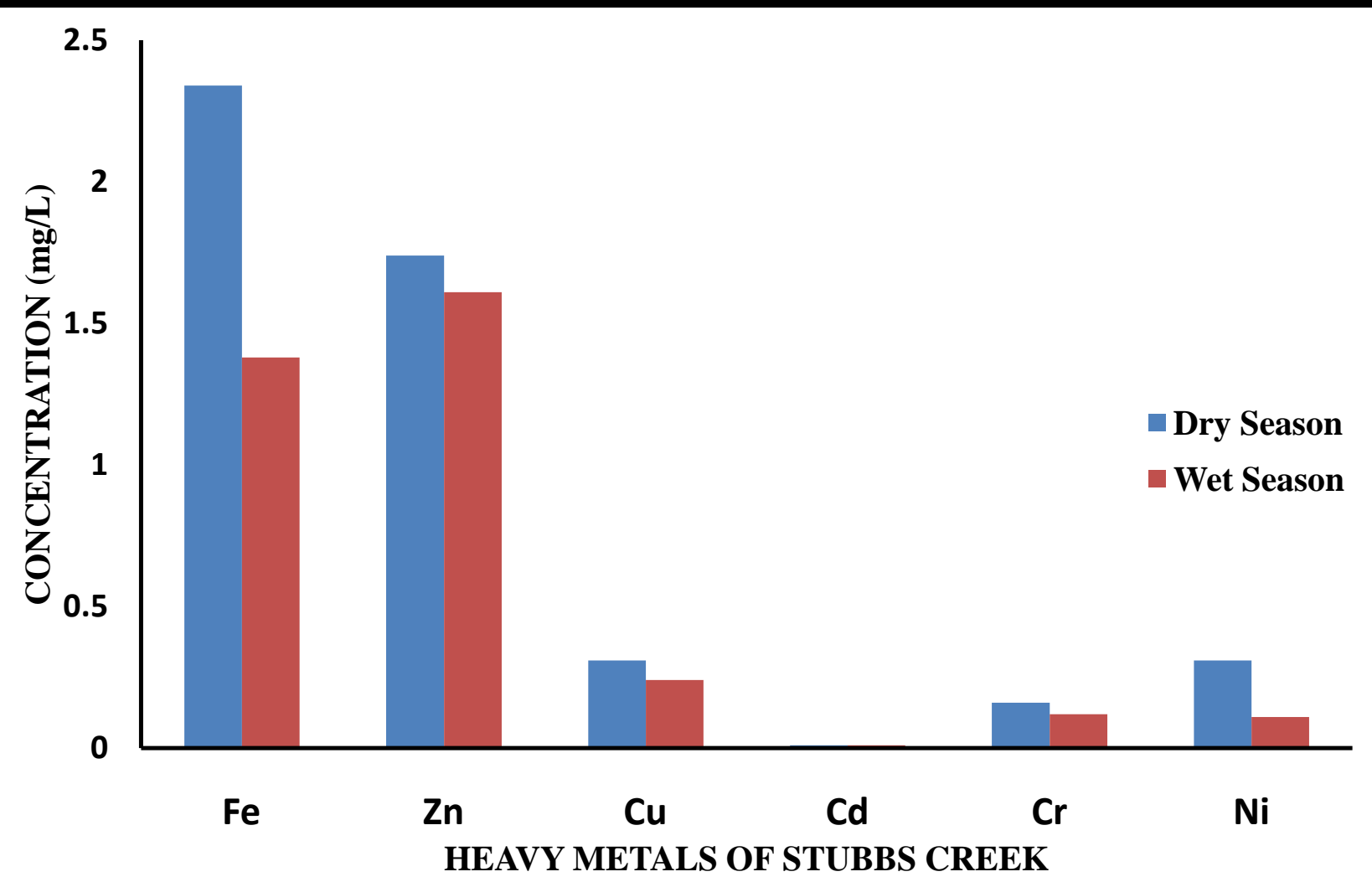

Figure 2: Seasonal Concentration of metals in water sample of Stubbs creek 


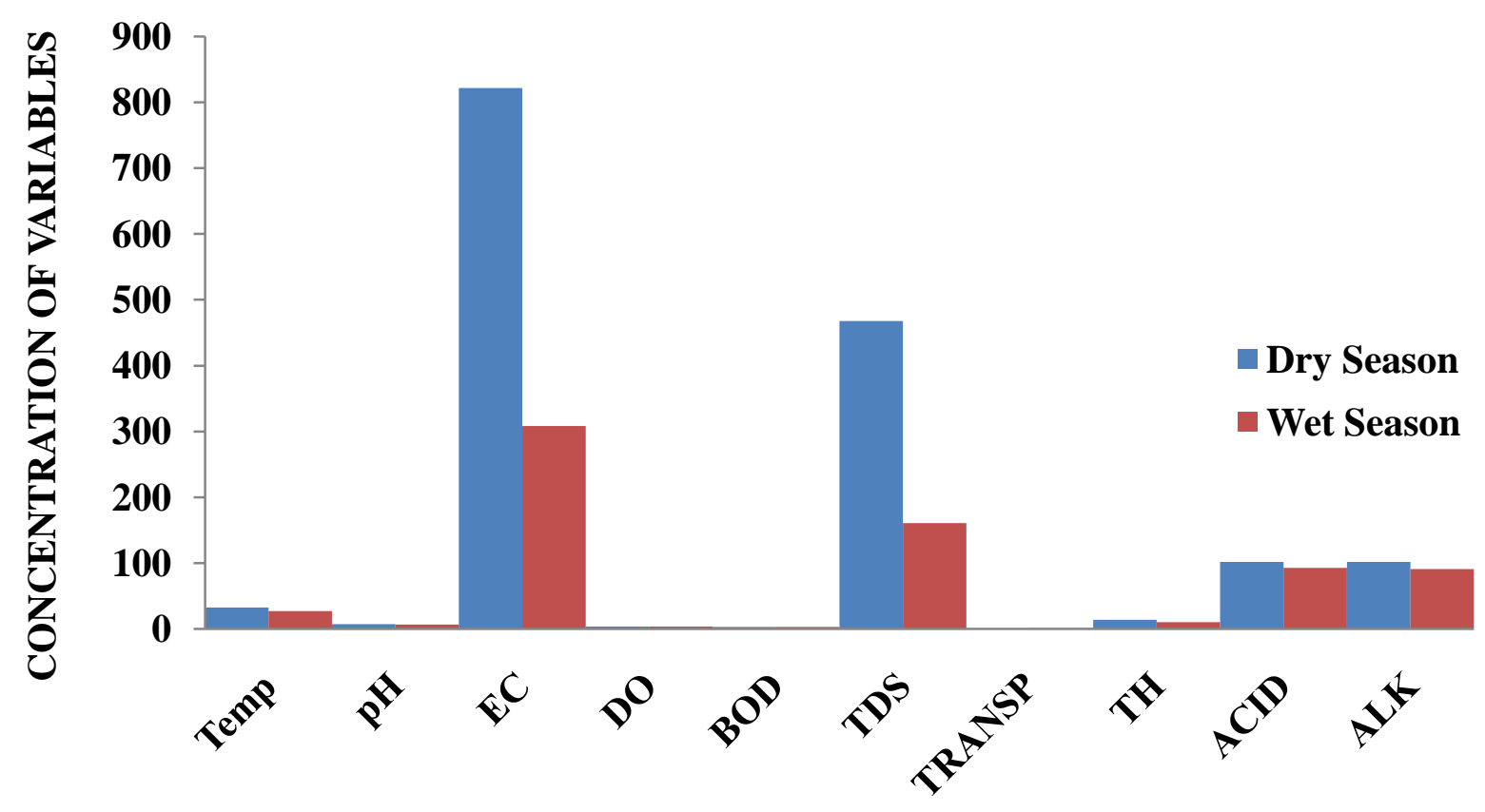

PHYSICO-CHEMICAL PARAMETERS

Figure 3: Seasonal variation of water physico- chemical parameters in Stubbs creek 